\title{
Evaluation of Anti-Photoaging Effects of a Novel Cosmeceutical Containing a Retinoids Mixture Using In Vitro Cell Models
}

\author{
Nicola Zerbinati ${ }^{1}$, Sabrina Sommatis ${ }^{2}$, Cristina Maccario ${ }^{2}$, Maria Chiara Capillo ${ }^{2}$, Serena Di Francesco ${ }^{2}$, \\ Elsa Liga ${ }^{2}$, Raffaele Rauso ${ }^{3}{ }^{\circledR}$, Edoardo D’Este ${ }^{4}$, Daniela Dalla Gasperina ${ }^{1} \mathbb{D}$, Stefania Guida ${ }^{5}$ \\ and Roberto Mocchi ${ }^{2, *}$
}

check for updates

Citation: Zerbinati, N.; Sommatis, S.; Maccario, C.; Capillo, M.C.; Di Francesco, S.; Liga, E.; Rauso, R.; D’Este, E.; Dalla Gasperina, D.; Guida S.; et al. Evaluation of Anti-Photoaging Effects of a Novel Cosmeceutical Containing a Retinoids Mixture Using In Vitro Cell Models. Appl. Sci. 2021, 11, 9992. https://doi.org/10.3390/app11219992

Academic Editors: Anca Pop,

Felicia Loghin, Catalina Bogdan and Ionel Fizesan

Received: 8 September 2021

Accepted: 21 October 2021

Published: 26 October 2021

Publisher's Note: MDPI stays neutra with regard to jurisdictional claims in published maps and institutional affiliations.

Copyright: (c) 2021 by the authors. Licensee MDPI, Basel, Switzerland. This article is an open access article distributed under the terms and conditions of the Creative Commons Attribution (CC BY) license (https:// creativecommons.org/licenses/by/ $4.0 /)$.
1 Department of Medicine and Surgery, University of Insubria, 21100 Varese, Italy; nicola.zerbinati@uninsubria.it (N.Z.); d.dallagasperina@uninsubria.it (D.D.G.)

2 UB-CARE, Spin-Off University of Pavia, 27100 Pavia, Italy; sabrina.sommatis@ub-careitaly.it (S.S.); cristina.maccario@ub-careitaly.it (C.M.); mariachiara.capillo@ub-careitaly.it (M.C.C.); serena.difrancesco@ub-careitaly.it (S.D.F.); quality@ub-careitaly.it (E.L.)

3 Department of Maxillofacial Surgery, University of Campania "Luigi Vanvitelli", 81100 Caserta, Italy; raffaele.rauso@unicampania.it

4 Department of Dermatology, Centro Medico Polispecialistico, 27100 Pavia, Italy; edeste@centro-medico.it

5 Dermatology Unit, Department of Surgical, Medical, Dental and Morphological Sciences Related to Transplant, Oncology and Regenerative Medicine, University of Modena and Reggio Emilia, 41125 Modena, Italy; stefania.guida@unimore.it

* Correspondence: roberto.mocchi@ub-careitaly.it

\begin{abstract}
Physiological ageing due to the passing of time and prolonged exposure to harmful sun rays generate wrinkles and reduce skin elasticity. These visible and clinical signs can be prevented or reversed by known strategies, such as the daily use of cosmetic products with antioxidant combinations or retinoids. A new dermocosmetic formulation enriched with a complex of retinoids, called RETINOIDS SERUM, was investigated through in vitro assays using human skin cells. The experiments were carried out to assess the anti-ageing activity in normal human dermal fibroblasts (NHDF) and epidermal keratinocytes (HaCaT). After the preliminary MTT assay, the proliferation together with the synthesis of collagen and elastin fibers was performed on NHDF cells after $24 \mathrm{~h}$ treatment with the two non-cytotoxic concentrations. Using UVB-irradiated HaCaT cells, the measurement of matrix metalloproteinase-1 (MMP-1) levels was also investigated. In vitro studies show that the dermocosmetic product improves collagen and elastin synthesis and the renewal of dermal fibroblasts. Moreover, a reduction in the MMP-1 secretion was also highlighted in UVB-irradiated HaCaT cells. These results suggest that the cosmetic formulation containing functional compounds such as retinoids can be useful to prevent the natural sign of ageing.
\end{abstract}

Keywords: cell culture; claim substantiation; formulation; skin ageing; retinoids; photoprotection

\section{Introduction}

The skin, whose main role is to defend the body from external agents, presents also an important role that cannot be underestimated: feeling young and healthy, which helps in the social context [1]. However, this protection can be compromised with ageing due to reduced epidermal thickness and increased in wrinkles and dryness. Skin ageing is a complex biological process influenced by a combination of many factors related to intrinsic events as genetics, hormonal changes and metabolic processes, whereas ultraviolet (UV) radiation, pollution, or chemical exposure are more associated with environmental stressors (extrinsic events). All these factors lead to gradual but cumulative alterations where the formation of wrinkles, loss of elasticity, thinning of the skin, and roughness are some examples. Almost all of them are correlated with reduced extracellular matrix (ECM) proteins, especially collagen and elastin in the dermis [2,3]. Collagen fibers represent the main component of ECM and they are responsible for the structural integrity and tensile 
strength of our body. Among 28 different types of collagens, types I and III are the most represented in the skin, with about $90 \%$ and $10 \%$ of the total. This proportion changes with age, highlighting a reduction approximately of $1.5 \%$ per year of the collagen produced together with an increase in its fragmentation. As shown by Fischer and colleagues, quantitative biochemical analysis showed that people with advanced age ( 80 years) had a quantity of fragmented collagen 4.3 times greater than in younger people aged between 21 and 30 years (in the human dermis) in vivo [4]. Elastin has the main function of providing elasticity to the tissues, being 10,000 times more flexible than collagen itself [5]. With ageing, the number of elastin fibers is also reduced. In addition to the physiological decay, chronic exposure to sunlight, in particular UV radiation, can cause a further worsening of the normal functions and characteristics of the skin. Among solar radiations, UVB are the most damaging rays, capable to induce DNA damage and the generation of excessive reactive oxygen species (ROS) production. ROS induce the activation of the mitogen-activated protein kinase (MAPK) cascade and the transcription factor named activator protein-1 (AP-1). The latter, in turn, regulates the transcription of metalloproteinases (MMPs), a large and complex family of zinc-dependent endopeptidases, able to break down almost all of the ECM components [6]. The MMPs can be classified according to their domains structure into collagenases, gelatinases, stromelysins, and matrilysins. Among all MMPs, the interstitial collagenase metalloproteinase-1 (MMP-1) is the most investigated. Its protease activity is addressed towards type I and III of collagens and it is produced by epidermal keratinocytes and dermal fibroblasts [7-9]. On the other side, many of these features are targets of the majority anti-ageing application or procedures for research strategies pertaining to the skin, from "anti-wrinkle creams" to various filling agents. It is noteworthy that the topical application of cosmetic products supplemented with functional compounds as antioxidant combinations or retinoids represents a valid way to contrast the signs of ageing. In this study, the effects of RETINOIDS SERUM (Matex Lab Spa, Brindisi, Italy) were taken under investigation for its innovative formulation enriched with vitamin A derivative characterized by a $1 \%$ of a retinoids mix including $0.1 \%$ of retinol, $0.1 \%$ retinaldehyde, and $1 \%$ of bioretinol. The retinoid class includes vitamin A (retinol), a 20-carbon molecule characterized by a cyclohexenyl ring and an alcohol end group, and its synthetic and natural derivatives (retinaldehyde, retinoic acid, and retinyl esters). Retinoids are required in many cellular processes, such as cell growth and differentiation, apoptosis, inflammation, and immune modulation. Many of their molecular mechanisms are mediated by the interaction with specific cellular and nucleic acid receptors as the Cellular Retinoic Acid Binding Protein (CRABP) types I and II [10]. In the skin, retinoids play a key role in inducing keratinocyte cell differentiation with a reduction in epidermis cell adhesion and fibroblast proliferation enhancing also collagen and elastin fibrils synthesis [11]. To demonstrate the anti-ageing efficacy of the product containing the retinoids mix, in vitro experiments were carried out in two of the most representative cell lines of the human skin: human dermal fibroblasts to evaluate the proliferation and the production of collagen and elastin fibers and epidermal keratinocytes to investigate the MMP-1 secretion after UVB-radiation.

\section{Materials and Methods}

\subsection{Sample Preparation and Reagents}

The functional product that was tested contained $1 \%$ of a retinoid mix $(0.1 \%$ of retinol, $0.1 \%$ retinaldehyde, and $1 \%$ of bioretinol). To perform the experimental panel, the product was solubilized at a concentration of $10 \mathrm{mg} / \mathrm{mL}$ in a specific culture medium for both cell lines. All the chemical reagents used were provided from Merck (Darmstadt, Germany) unless otherwise specified.

\subsection{Cell Cultures and UVB Irradiation}

Normal human dermal fibroblasts (NHDF, code CC-2511) were purchased from Lonza (Basel, Switzerland), while human immortalized keratinocytes (HaCaT, code BS CL 168) were provided by I.Z.L.E.R (Istituto Zooprofilattico della Lombardia e Emilia Romagna, 
Italy). Both cell lines were grown in a cell culture medium constituted by Dulbecco's Modified Eagle's Medium (DMEM-Lonza, Basel, Switzerland) High Glucose with 10\% fetal bovine serum (FBS-Thermo Fisher Scientific, Monza, Italy) and 1\% of L-glutamine and antibiotics (penicillin G sodium and streptomycin sulfate-Lonza, Basel, Switzerland), in conditions of complete sterility and maintained in incubation at $37^{\circ} \mathrm{C}$ with $5 \%$ carbon dioxide $\left(\mathrm{CO}_{2}\right)$ atmosphere. For the irradiation protocol, cells were seeded in a 6-well plate for $24 \mathrm{~h}$ and then the treatment with the product for further $24 \mathrm{~h}$ was performed. The day after, cells were washed with phosphate buffer saline (PBS) and exposed to UVB lamp (CAMAG ${ }^{\circledR}$ UV Lamp 4, wavelength $302 \mathrm{~nm}$-Muttenz, Switzerland) with a dose equal to $5 \mathrm{~mJ} / \mathrm{cm}^{2}$. After irradiation, cells were maintained in a complete medium for a recovery time of $24 \mathrm{~h}$ at $37^{\circ} \mathrm{C}$ before cell supernatant recovery. Untreated cells were used as control in all experimental sets.

\subsection{Cytotoxicity Assay (MTT Test)}

The preliminary cytotoxicity assay was performed using the MTT (3-[4,5-dimethylthiazol-2-yl]-2,5 diphenyl tetrazolium bromide) reagent [12]. NHDF and HaCaT cells were homogeneously seeded in 96-well plates with a density equal to $2 \times 10^{4}$ cells per well. After $24 \mathrm{~h}$, cells were treated with different concentrations of product, starting from $10 \mathrm{mg} / \mathrm{mL}$ and following dilution (1:2 ratio), prepared directly in a complete culture medium for NHDF, while, starting from $5 \mathrm{mg} / \mathrm{mL}$ and following dilution (1:2 ratio) in medium containing $0.5 \%$ FBS for HaCaT cells. After subsequent $24 \mathrm{~h}$ of treatment, plates were processed with $50 \mu \mathrm{L}$ of MTT solution $(1 \mathrm{mg} / \mathrm{mL})$ at $37{ }^{\circ} \mathrm{C}$ for $2 \mathrm{~h}$. Afterwards, the supernatant was discarded and $100 \mu \mathrm{L}$ of isopropanol was added to each well. Absorbance was read at $560 \mathrm{~nm}$ using a microplate reader (Glomax ${ }^{\circledR}$, Promega Corporation, Madison, WI, USA). Cell survival was obtained by measuring the difference in optical density (OD) of the tested product at all concentrations with respect to control (untreated cells).

$$
\text { Cell viability }(\%)=[\text { OD570nm test product/OD570nm control }] \times 100
$$

\subsection{BrdU Incorporation Assay}

To investigate the proliferation rate, a synthetic analogue of the pyrimidine deoxynucleoside thymidine, the 5-bromo-2'-deoxyuridine (BrdU), was used. NHDF cells were seeded on a coverslip into Petri dishes. After $24 \mathrm{~h}$, the two non-cytotoxic concentrations of the product were chosen to treat cells for other $24 \mathrm{~h}$. Subsequently, cells were incubated with BrdU during the last hour of culture and then fixed with $70 \%$ ethanol for $2 \mathrm{~h}$ at $-20{ }^{\circ} \mathrm{C}$. After a fixation step, the samples were washed for $30 \mathrm{~min}$ with blocking solution, composed of $0.4 \%$ Triton-X, $1 \%$ bovine serum albumin (BSA) in PBS, incubated first with anti-BrdU antibody (clone B44-Becton Dickinson, Sunnyvale, CA, USA) for $1 \mathrm{~h}$ and then with a FITC-conjugated antibody (Alexa Fluor 488-Thermo Fisher Scientific, Monza, Italy) for $30 \mathrm{~min}$. At the end of the assay, coverslips were washed, counterstained for DNA with Hoechst 33258, and mounted on microscope slides. Visualization was performed with a Nikon Eclipse E400 fluorescence microscopy (Minato, Tokyo, Japan), equipped with a Canon A590 IS camera.

\subsection{Collagen Quantitative Analysis}

The quantity of the collagen secreted by dermal fibroblasts was measured using a colorimetric kit Sircol $^{\mathrm{TM}}$, Soluble Collagen Assay Kit-Biocolor Life Science, Carrickfergus, UK). NHDF cells were homogeneously seeded with an $8 \times 10^{4}$ cells/well density in a 24 well plate. After $48 \mathrm{~h}$, two of the tested product concentrations proved to be non-cytotoxic and presenting the best solubility in culture medium were chosen. The measurement of collagen synthesis was performed following the manufacturer's instructions. Briefly, at the end of incubation, $200 \mu \mathrm{L}$ of Tris- $\mathrm{HCl}$ pH 7.4 containing polyethylene glycol were added to the recovered supernatant for the isolation and concentration of collagen, then stored overnight at $4{ }^{\circ} \mathrm{C}$. The day after, samples were centrifuged at 12,000 rpm and incubated for $10 \mathrm{~min}$ with a Sircol dye reagent able to bind collagen. During this phase, 
the coloured complex that forms, tends to precipitate. After centrifugation $(12,000 \mathrm{rpm}$ for $10 \mathrm{~min}$ ), a reagent containing sodium hydroxide $0.5 \mathrm{M}$, was added to solubilize the collagen precipitated. Lastly, $200 \mu \mathrm{L}$ of the sample were collected and placed into a 96 well-plate for spectrophotometric OD reading at a wavelength of $555 \mathrm{~nm}$ (Multiskan, Thermo Scientific, Waltham, MA, USA). The final concentration of collagen $(\mu \mathrm{g} / \mathrm{mL})$ was calculated using a standard curve $(0-10 \mu \mathrm{g} / \mathrm{mL})$.

\subsection{Elastin Quantitative Analysis}

Total elastin, as $\alpha$-elastin (soluble tropoelastin, lathyrogenic elastin and insoluble elastin), was evaluated in NHDF cells after $24 \mathrm{~h}$ treatment, using a colorimetric kit (Fastin ${ }^{\mathrm{TM}}$, Elastin Assay kit-Biocolor Life Science Assays, Carrickfergus, UK). For the preparation of the assay, cells were homogeneously seeded in a 12-well plate at $1.8 \times 10^{5}$ and incubated at $37^{\circ} \mathrm{C}$. After $48 \mathrm{~h}$, the same concentrations chosen for the collagen test were used. At the end of treatment, cells were detached with a cell dissociation solution and diluted 3:1 with $1 \mathrm{M}$ oxalic acid (final concentration $0.25 \mathrm{M}$ ). Subsequently, samples were incubated at $95 \pm 5{ }^{\circ} \mathrm{C}$ for $1 \mathrm{~h}$ with intermittent mixing, and then the measurement of elastin produced by each sample was performed following the manufacturer's instructions.

\subsection{Analysis of $M M P-1$ Expression}

For the measurement of MMP-1 production, an ELISA kit (MMP-1 Human, Biotrak ELISA System-Amersham, GE Healthcare, Buckinghamshire, UK) was used. HaCaT cells were homogeneously seeded in 6-well plates and incubated at $37^{\circ} \mathrm{C}$. After $24 \mathrm{~h}$, the two highest concentrations of the product $(0.313$ and $0.625 \mathrm{mg} / \mathrm{mL})$ demonstrated to be non-cytotoxic after a preliminary MTT assay, were chosen to be tested in this assay. After treatment and a rapid wash with PBS, cells were irradiated with a single sub-toxic UVB dose $\left(5 \mathrm{~mJ} / \mathrm{cm}^{2}\right)$ as a good MMPs stimulator and incubated at $37{ }^{\circ} \mathrm{C}$ with $5 \% \mathrm{CO}_{2}$ for a further $24 \mathrm{~h}$. UVB-irradiated cells were used as a positive control. Subsequently, cell culture supernatants were collected and the concentration of MMP-1 in each sample was determined by interpolation from a 4PL standard curve (6.25-100 ng/mL).

\subsection{Statistical Analysis}

Data are presented as mean \pm standard deviation (SD) of at least three independent experiments performed in duplicate. Statistical significance was calculated in all experimental sets using the One-way ANOVA followed by Fisher's LSD multiple comparisons posttest by the GraphPad Prism version 9.0.0 software (GraphPad Software, Inc., San Diego, CA, USA) and differences with $p$ values $<0.05$ were considered statistically significant compared to the relative controls.

\section{Results}

\subsection{Evaluation of MTT Assay}

MTT test was performed to study the cell viability of NHDF and HaCaT cells to select the concentrations that do not cause a decrease in cell respiration exceeding $20 \%$. NHDF cells were treated with scalar concentrations of the product $(0.625-10 \mathrm{mg} / \mathrm{mL})$ for $24 \mathrm{~h}$. $\mathrm{HaCaT}$ cells were treated with scalar concentrations starting from $5 \mathrm{mg} / \mathrm{mL}$ (range tested $0.313-5 \mathrm{mg} / \mathrm{mL}$ ) at $0.5 \% \mathrm{FBS}$, for $24 \mathrm{~h}$. Figure 1 shows that increasing concentrations of the product induce a dose-dependently reduction of cell viability. The first two noncytotoxic concentrations having a viability $>80 \%$ were identified in 0.625 and $1.25 \mathrm{mg} / \mathrm{mL}$ in NHDF cells (Figure 1A), whereas 0.313 and $0.625 \mathrm{mg} / \mathrm{mL}$ in HaCaT cells (Figure 1B). These concentrations were then used for the subsequent experiments. 


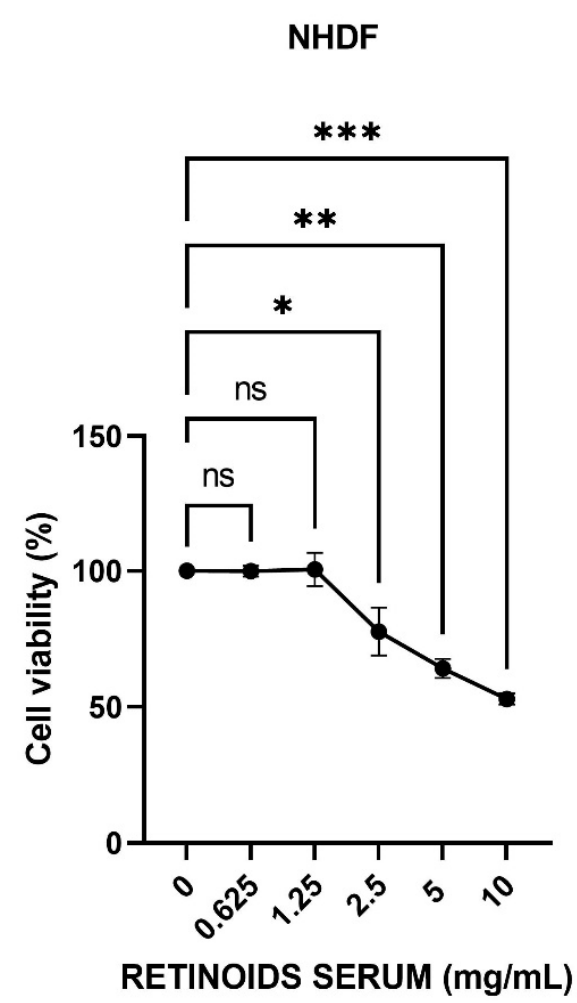

(A)

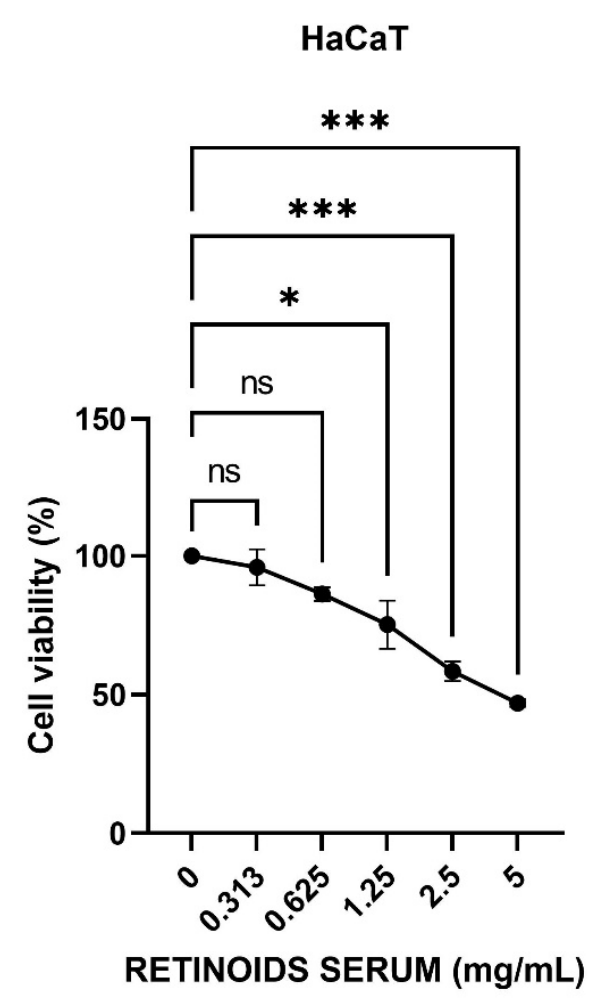

(B)

Figure 1. Cell viability expressed as a percentage (mean \pm SD) after $24 \mathrm{~h}$ of treatment on NHDF (A) and HaCaT cells (B) after treatment with the RETINOIDS SERUM compared to the control (untreated cells) $(n=3$, replicates $=3)$. Values of ${ }^{*} p<0.05$ and ${ }^{* *} p<0.01$ and ${ }^{* * *} p<0.001$ were considered statistically significant.

\subsection{Evaluation of Cell Proliferation}

After cytotoxicity evaluation, the product was tested on dermal fibroblasts to evaluate its proliferative capacity to promote cell renewal by the BrdU assay. NHDF cells were treated with the two highest non-cytotoxic concentrations $(0.625$ and $1.25 \mathrm{mg} / \mathrm{mL})$ for $24 \mathrm{~h}$. In Figure 2, treatment with the product showed a greater proliferative rate compared to untreated cells (CTRL). After $24 \mathrm{~h}$ treatment with $0.625 \mathrm{mg} / \mathrm{mL}$, the percentage of BrdU positive cells was equal to $55.12 \%$ versus $38.46 \%$ of control cells, indicating a significant increase of $43 \%$ ( $^{*} p$ values $\left.\leq 0.05\right)$. A similar result was confirmed after treatment with the highest concentration used of $1.25 \mathrm{mg} / \mathrm{mL}$ ( $+32 \%$ compared to untreated cells, ${ }^{*} p$ values $\left.\leq 0.05\right)$.

\subsection{Evaluation of Collagen Synthesis}

Collagen is the main structural protein in connective tissue and fibroblasts are the cell population most responsible for its synthesis. To evaluate the capability of the product to modulate collagen production and therefore to perform its function as an anti-ageing product, NHDF cells were treated with 0.625 and $1.25 \mathrm{mg} / \mathrm{mL}$ of the tested product. Considering the different types of collagen found in the skin, a colorimetric assay capable to measure collagens from types I to $\mathrm{V}$ produced in in vitro cell culture was performed. The obtained results demonstrate that the product determines a significant increase in the level of newly synthesized collagen equal to $230 \%$ and $386 \%$ after treatment with 0.625 and $1.25 \mathrm{mg} / \mathrm{mL}$, respectively, compared to control (untreated cells) (Figure 3). 

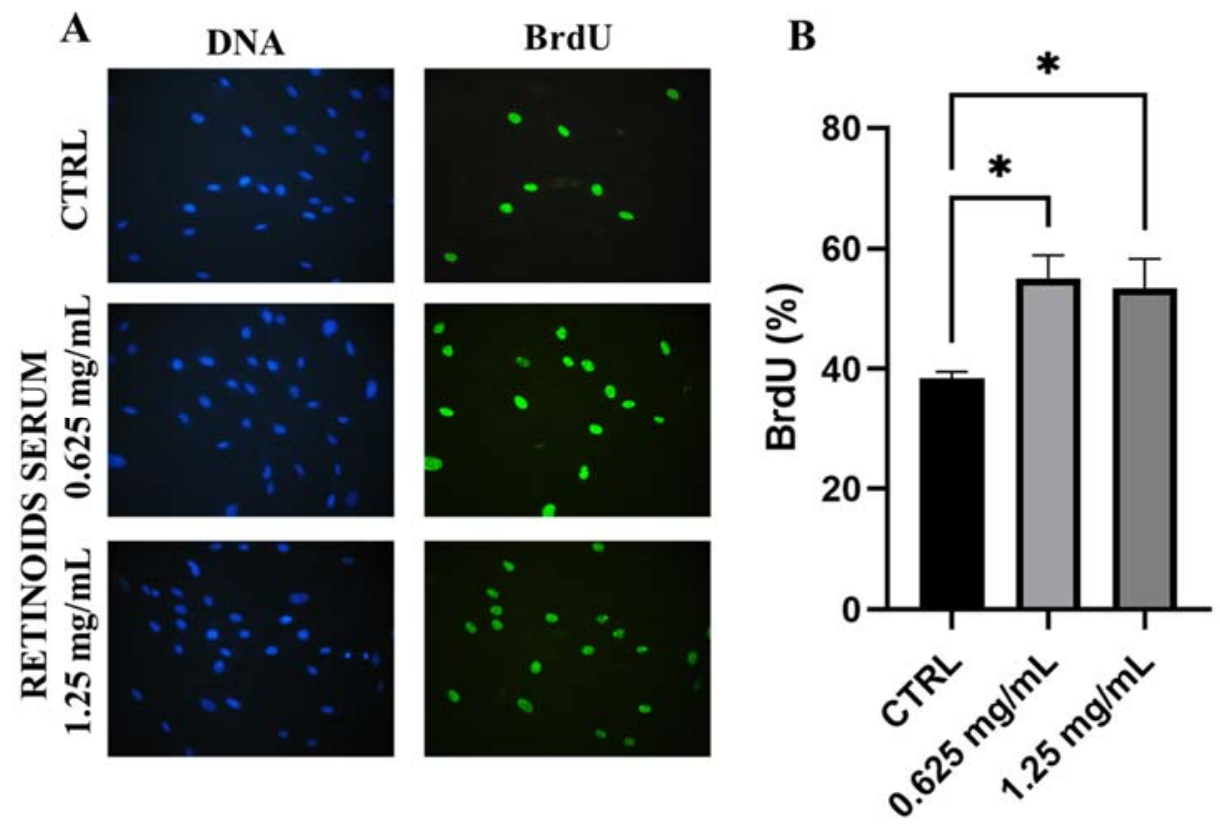

Figure 2. Representative images of immunofluorescence BrdU assay (A) DNA is marked in blue with Hoechst 33258 while BrdU is visible in green. (B) Quantitative assessment of BrdU positive cells expressed as a percentage (mean $\pm \mathrm{SD}$ ) compared to control after $24 \mathrm{~h}$ of treatment with the RETINOIDS SERUM (0.625 and $1.25 \mathrm{mg} / \mathrm{mL})$. Values of * $p<0.05$ were considered statistically significant compared to untreated cells (CTRL).

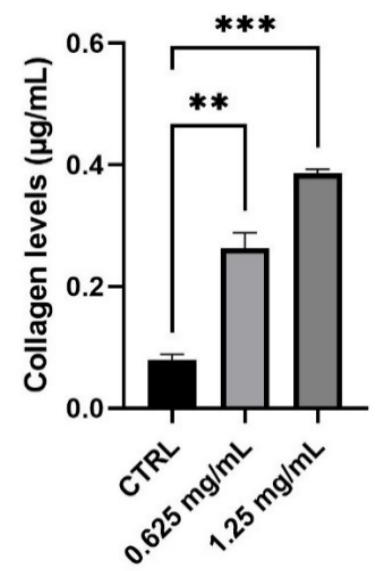

Figure 3. Collagen levels expressed as $\mu \mathrm{g} / \mathrm{mL}$ (mean $\pm \mathrm{SD}$ ) after treatment with the RETINOIDS SERUM compared to control (CTRL, untreated cells). Values of ${ }^{* *} p<0.01$ and ${ }^{* * *} p<0.001$ were considered statistically significant compared to CTRL $(n=3$, replicates $=2)$.

\subsection{Evaluation of Elastin Synthesis}

Together with collagen, elastin is the second principal component of ECM representing $2 \%$ of the dermis weight. Its role is closely linked to collagen fibers and it is mainly responsible for the elasticity of the skin. After evaluating the production of new collagen in normal human dermal fibroblasts, the synthesis of elastin was also investigated after $24 \mathrm{~h}$ treatment with 0.625 and $1.25 \mathrm{mg} / \mathrm{mL}$. As shown in Figure 4, treatment with the product determines a significant increase in elastin levels. In particular, the amount of elastin measured results to be statistically significant with an increase equal to $77 \%$ after treatment with the highest concentration $(1.25 \mathrm{mg} / \mathrm{mL})$ of the tested product ${ }^{* *} p$ values $\left.\leq 0.01\right)$. 


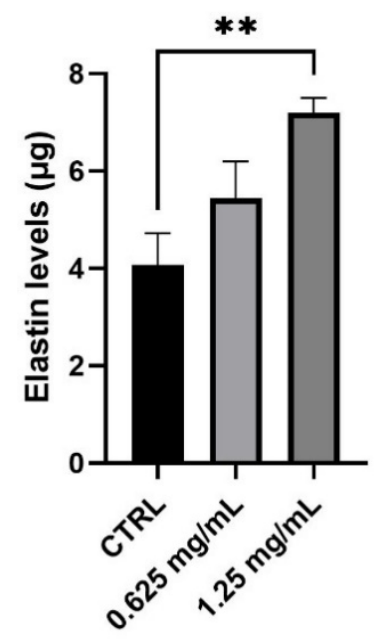

Figure 4. Elastin levels expressed as $\mu \mathrm{g}$ (mean $\pm \mathrm{SD}$ ) after treatment with the RETINOIDS SERUM compared to control (CTRL, untreated cells) in NHDF cells. Values of ${ }^{* *} p<0.01$ were considered statistically significant compared to CTRL $(n=3$, replicates $=2)$.

\subsection{Evaluation of MMP-1 Levels}

Alterations in the expression of MMP-1 is correlated predominantly to skin photoaging. The possible protection from MMP-1 production was investigated in $\mathrm{HaCaT}$ cells using $\mathrm{UVB}$ as a source of irradiation. After $24 \mathrm{~h}$ treatment, $\mathrm{HaCaT}$ cells were treated with the highest non-cytotoxic concentrations of 0.313 and $0.625 \mathrm{mg} / \mathrm{mL}$ and UVB irradiation. As shown in Figure 5, the results demonstrated that UVB irradiation markedly increases the MMP-1 production by $55 \%$ ( $^{* * *} p$ values $\leq 0.001$ ), compared to non-irradiated control cells (CTRL). In UVB condition, treatment with the product at the two non-cytotoxic concentrations induced a modest reduction of MMP-1 levels after $24 \mathrm{~h}$, compared to the positive control cells (UVB). In particular, it is possible to observe a significant reduction of $24 \%$ and $31 \%$ after treatment with 0.313 and $0.625 \mathrm{mg} / \mathrm{mL}$ of the product, respectively ${ }^{* *} p$ values $\left.\leq 0.01\right)$.

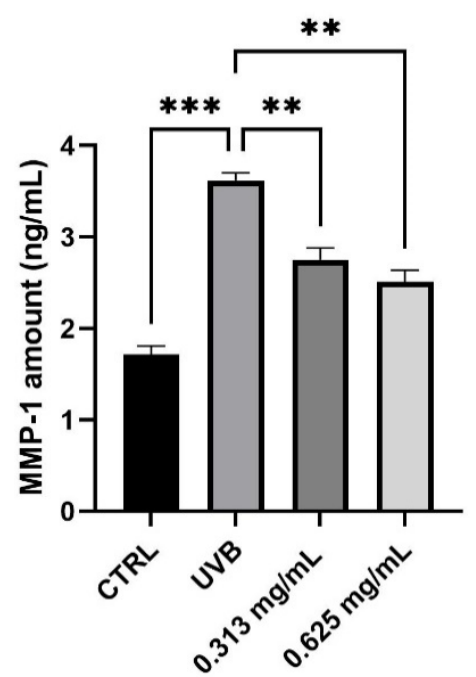

Figure 5. MMP-1 levels measured in $\mathrm{ng} / \mathrm{mL}$ (mean $\pm \mathrm{SD}$ ) after treatment with the RETINOIDS SERUM at the concentrations of 0.313 and $0.625 \mathrm{mg} / \mathrm{mL}$ in HaCaT cells. CTRL: untreated cells; UVB: irradiated cells. Values of ${ }^{* *} p<0.01$ and ${ }^{* *} p<0.001$ were considered statistically significant.

\section{Discussion}

The aesthetic condition of the skin is gaining importance over the years because of its social impact. The appearance of expression lines that become with age deep wrinkles, 
loss of tone and elasticity of the skin, irregular pigmentation together with a reduction in the thickness of the epidermis and dermis, represent the typical signs of skin-ageing. All of these changes are induced by chronological ageing or can be accelerated by the externals factor [13]. Several studies prove that a daily and constant use of cosmetic products enriched with functional compounds, such as vitamins, can help to counteract the signs of ageing and photoaging. In particular, in the last two decades, retinoids such as vitamin $\mathrm{A}$ and its derivates, have been frequently added to cosmetic formulations. All of them have important effects on skin cells: they can stimulate or maintain the skin keratinocyte's differentiation from the basal layer to the most superficial one, they are fundamental in epidermal renewal both caused by normal skin turnover or in case of injury, and they also influence the ECM composition. Several in vitro and in vivo studies demonstrate the ability of retinol and its derivatives to penetrate across the epithelium exerting a biological effect in keratinocyte cells differentiation, corneocyte exfoliation, and regulating fibroblast proliferation in the dermis by angiogenesis, collagen and elastin synthesis stimulation $[14,15]$. The retinoids receptor signaling mediated by the interaction with specific nuclear receptors, such as retinoid $X$ receptors (RXRs) and retinoic acid receptors (RARs), increases the production of procollagen, thus leading to the synthesis of new collagen and, at the same time, inhibits Matrix Metalloproteinases (MMPs) [16-22]. In addition, many articles show the potential effect of a new dermocosmetic containing retinaldehyde (RAL), delta-tocopherol glucoside, and glycylglycine oleamide with in vitro and clinical studies as well as the restoration and the improvement of the ECM complex in UV-irradiated fibroblast models [23-27]. In our study, we investigated the in vitro effects of a new formulation produced by Matex Lab Spa, containing vitamin A derivatives in a mix that included $0.1 \%$ of retinol, $0.1 \%$ retinaldehyde, and $1 \%$ of bioretinol, using human dermal fibroblasts (NHDF) and epidermal keratinocytes (HaCaT). First of all, the viability on the selected cell models was evaluated by the MTT assay to identify the first two non-cytotoxic concentrations to perform efficacy tests. The obtained results showed $0.625-1.25 \mathrm{mg} / \mathrm{mL}$ and $0.313-0.625 \mathrm{mg} / \mathrm{mL}$ for NHDF and HaCaT cells, respectively. The different concentrations are the result of a different sensitivity of the two cell lines to the RETINOIDS SERUM and to the reduced concentration of serum in the MTT performed on HaCaT cells (0.5\% FBS). Once the product's concentrations to be tested were identified, the efficacy tests were performed on the relevant cell lines. In order to verify the ability to enhance the proliferation process, a 5-bromo-2'-deoxyuridine (BrdU) assay was performed showing a statistical increase of the proliferative rate of NHDF cells after $24 \mathrm{~h}$ treatment with the two non-cytotoxic concentrations $(0.625$ and $1.25 \mathrm{mg} / \mathrm{mL})$. Since the proliferative capacity of fibroblasts is frequently associated with the production of the ECM complex, then we studied the serum effect on the synthesis of collagen and elastin proteins. Our investigations showed that the product increased the secretion of these ECM components in a significant way in dermal fibroblasts. At the same time, we focused on assessing the effect of the dermocosmetic serum on human keratinocytes. In particular, we set up a photoaging model induced by exposure to UV rays evaluating the matrix metalloproteinases (MMPs) production by keratinocytes after UVB radiation. Among the MMPs, MMP-1 cleaves fibrillary collagen type I which is the most present protein in the connective tissue of the skin. Therefore, the photoprotective capacity of the serum was investigated through the measurement of MMP-1 levels. The obtained results showed a marked and statistically significant reduction of secreted MMP-1 in UVB-radiated HaCaT cells with the highest tested concentration of $0.625 \mathrm{mg} / \mathrm{mL}$.

\section{Conclusions}

Retinoids and derivatives are often used as cosmetic ingredients for anti-ageing treatment and their effectiveness in complex formulas must be tested in appropriate in vitro models. In our study we investigated the effectiveness of the RETINOIDS SERUM as a retinoids-based formulation in the anti-ageing treatment, and collectively our data demonstrated a notable effect on the main molecules involved in the ageing process, 
stimulating the collagen and elastin synthesis, and at the same time decreasing the MMP-1 production in NHDF and HaCaT cell models, respectively.

Author Contributions: Conceptualization, C.M., S.S. and R.M.; methodology, C.M., S.S. and R.M.; formal analysis, M.C.C., S.D.F. and E.L.; investigation, M.C.C., S.D.F. and E.L.; writing-original draft preparation, M.C.C.; writing-review and editing, R.M.; visualization, R.R., E.D., D.D.G. and S.G.; supervision, R.M. and N.Z.; project administration, N.Z. and R.M. All authors have read and agreed to the published version of the manuscript.

Funding: This research was funded by Matex Lab S.p.a.

Institutional Review Board Statement: Not applicable.

Informed Consent Statement: Not applicable.

Data Availability Statement: Data are included in the text; raw data are available from the corresponding author upon request.

Conflicts of Interest: N.Z. is the Scientific Director of Matex Lab S.p.a. The authors declare no other conflicts of interest.

\section{References}

1. Zhang, S.; Duan, E. Fighting against Skin Aging: The Way from Bench to Bedside. Cell Transpl. 2018, 27, 729-738. [CrossRef] [PubMed]

2. Shin, J.W.; Kwon, S.H.; Choi, J.Y.; Na, J.I.; Huh, C.H.; Choi, H.R.; Park, K.-C. Molecular Mechanisms of Dermal Aging and Antiaging Approaches. Int. J. Mol. Sci. 2019, 20, 2126. [CrossRef] [PubMed]

3. Farage, M.A.; Miller, K.W.; Elsner, P.; Maibach, H.I. Intrinsic and extrinsic factors in skin ageing: A review. Int. J. Cosmet. Sci. 2008, 30, 87-95. [CrossRef] [PubMed]

4. Fisher, G.J.; Quan, T.; Purohit, T.; Shao, Y.; Cho, M.K.; He, T.; Varani, J.; Kang, S.; Voorhees, J.J. Collagen fragmentation promotes oxidative stress and elevates matrix metalloproteinase-1 in fibroblasts in aged human skin. Am. J. Pathol. 2009, 174, 101-114. [CrossRef]

5. Weihermann, A.C.; Lorencini, M.; Brohem, C.A.; de Carvalho, C.M. Elastin structure and its involvement in skin photoageing. Int. J. Cosmet. Sci. 2017, 39, 241-247. [CrossRef] [PubMed]

6. Xuan, S.H.; Park, Y.M.; Ha, J.H.; Jeong, Y.J.; Park, S.N. The effect of dehydroglyasperin C on UVB-mediated MMPs expression in human HaCaT cells. Pharmacol. Rep. 2017, 69, 1224-1231. [CrossRef] [PubMed]

7. Docherty, A.J.; O'Connell, J.; Crabbe, T.; Angal, S.; Murphy, G. The matrix metalloproteinases and their natural inhibitors: Prospects for treating degenerative tissue diseases. Trends Biotechnol. 1992, 10, 200-207. [CrossRef]

8. Pittayapruek, P.; Meephansan, J.; Prapapan, O.; Komine, M.; Ohtsuki, M. Role of Matrix Metalloproteinases in Photoaging and Photocarcinogenesis. Int. J. Mol. Sci. 2016, 17, 868. [CrossRef] [PubMed]

9. Brennan, M.; Bhatti, H.; Nerusu, K.C.; Bhagavathula, N.; Kang, S.; Fisher, G.J.; Varani, J.; Voorhees, J.J. Matrix metalloproteinase-1 is the major collagenolytic enzyme responsible for collagen damage in UV-irradiated human skin. Photochem. Photobiol. 2003, 78, 43-48. [CrossRef]

10. Mukherjee, S.; Date, A.; Patravale, V.; Korting, H.C.; Roeder, A.; Weindl, G. Retinoids in the treatment of skin aging: An overview of clinical efficacy and safety. Clin. Interv. Aging 2006, 1, 327-348. [CrossRef] [PubMed]

11. Daly, T.J.; Weston, W.L. Retinoids effects on fibroblasts proliferation and collagen synthesis in vitro and on fibrotic disease in vivo. JAAD 1986, 15, 900-902. [CrossRef]

12. Mosmann, T. Rapid colorimetric assay for cellular growth and survival: Application to proliferation and cytotoxicity assays. J. Immunol. Methods 1983, 65, 55-63. [CrossRef]

13. Ganceviciene, R.; Liakou, A.I.; Theodoridis, A.; Makrantonaki, E.; Zouboulis, C.C. Skin anti-aging strategies. DermatoEndocrinology 2012, 4, 308-319. [CrossRef] [PubMed]

14. Jurzak, M.; Latocha, M.; Gojniczek, K.; Kapral, M.; Garncarczyk, A.; Pierzchała, E. Influence of retinoids on skin fibroblasts metabolism in vitro. Acta Pol. Pharm. 2008, 65, 85-91. [PubMed]

15. Lee, E.S.; Ahn, Y.; Bae, I.H.; Min, D.; Park, N.H.; Jung, W.; Kim, S.-H.; Hong, Y.D.; Park, W.S.; Lee, C.S. Synthetic Retinoid Seletinoid G Improves Skin Barrier Function through Wound Healing and Collagen Realignment in Human Skin Equivalents. Int. J. Mol. Sci. 2020, 21, 3198. [CrossRef] [PubMed]

16. Katsambas, A.D.; Katoulis, A.C. Topical retinoids in the treatment of aging of the skin. Adv. Exp. Med. Biol. 1999, 455, 477-482. [PubMed]

17. Griffiths, C.E. The role of retinoids in the prevention and repair of aged and photoaged skin. Clin. Exp. Dermatol. 2001, 26, 613-618. [CrossRef] [PubMed]

18. Zasada, M.; Budzisz, E. Retinoids: Active molecules influencing skin structure formation in cosmetic and dermatological treatments. Postepy Dermatol. Alergol. 2019, 36, 392-397. [CrossRef] 
19. Shigematsu, T.; Tajima, S. Modulation of collagen synthesis and cell proliferation by retinoids in human skin fibroblasts. J. Derm. Sci. 1995, 9, 142-145. [CrossRef]

20. Kligman, A.M.; Leyden, J.J. Treatment of photoaged skin with topical tretinoin. Skin Pharmacol. 1993, 6, 78-82. [CrossRef] [PubMed]

21. Boisnic, S.; Branchet-Gumila, M.C.; Nocera, T. Comparative study of the anti-aging effect of retinaldehyde alone or associated with pretocopheryl in a surviving human skin model submitted to ultraviolet A and B irradiation. Int. J. Tissue React. 2005, 27, 91-99. [PubMed]

22. Rouvrais, C.; Baspeyras, M.; Mengeaud, V.; Rossi, A.B. Antiaging efficacy of a retinaldehyde-based cream compared with glycolic acid peel sessions: A randomized controlled study. J. Cosmet. Dermatol. 2018, 17, 1136-1143. [CrossRef] [PubMed]

23. Creidi, P.; Vienne, M.P.; Ochonisky, S.; Lauze, C.; Turlier, V.; Lagarde, J.M.; Dupuy, P. Profilometric evaluation of photodamage after topical retinaldehyde and retinoic acid treatment. J. Am. Acad. Dermatol. 1998, 39, 960-965. [CrossRef]

24. Sorg, O.; Saurat, J.H. Topical retinoids in skin ageing: A focused update with reference to sun-induced epidermal vitamin A deficiency. Dermatology 2014, 228, 314-325. [CrossRef]

25. Saurat, J.H.; Didierjean, L.; Masgrau, E.; Piletta, P.A.; Jaconi, S.; Chatellard-Gruaz, D.; Gumowski, D.; Masouyé, I.; Salomon, D.; Siegenthaler, G. Topical retinaldehyde on human skin: Biologic effects and tolerance. J. Investig. Dermatol. 1994, 103, 770-774. [CrossRef] [PubMed]

26. Stratigos, A.J.; Katsambas, A.D. The role of topical retinoids in the treatment of photoaging. Drugs 2005, 65, 1061-7102. [CrossRef] [PubMed]

27. Rouvrais, C.; Bacqueville, D.; Bogdanowicz, P.; Haure, M.J.; Duprat, L.; Coutanceau, C.; Castex-Rizzi, N.; Duplan, H.; Mengeaud, V.; Bessou-Touya, S. A new dermocosmetic containing retinaldehyde, delta-tocopherol glucoside and glycylglycine oleamide for managing naturally aged skin: Results from in vitro to clinical studies. Clin. Cosmet. Investig. Dermatol. 2017, 10, 35-42. [CrossRef] [PubMed] 